\title{
FAKTOR-FAKTOR PERILAKU PRO-LINGKUNGAN DALAM MENDUKUNG PELAKSANAAN IMPLEMENTASI CAMPUS SUSTAINABILITY
}

\author{
Asri Rachmawati ${ }^{*}$, Naniek Utami Handayani*) \\ Program Studi Teknik Industri, Fakultas Teknik, Universitas Diponegoro \\ Jl. Prof. Soedarto, SH, Tembalang, Semarang, 50285
}

\begin{abstract}
Abstrak
Perguruan tinggi memiliki peran penting dalam melindungi lingkungan di masa depan. Untuk mengembangkan Program keberlanjutan kampus memerlukan pemahaman tentang faktor-faktor penentu yang mempengaruhi perilaku pro-lingkungan. Tujuan dari penelitian ini adalah mengidentifikasi karakteristik perilaku pro-lingkungan. Penelitian menggunakan analisis faktor ini untuk mengurangi faktor penentu dan dilakukan survei untuk pengumpulan data. Alat survei menggunakan theory of planned behaviour (TPB) di seluruh kuesioner yang telah dibagikan kepada 400 mahasiswa. Hasil penelitian ini menyimpulkan perilaku pro-lingkungan dipengaruhi oleh sikap, norma subjektif, persepsi kendali perilaku, persepsi konsekuensi, faktor-faktor situasional, dan niat perilaku.
\end{abstract}

Kata Kunci : analisis faktor, campus sustainability, perilaku pro-lingkungan

\begin{abstract}
Universitieshave an important role in protecting the environment in the future. To develop campus sustainability programrequire an understanding about the determinant factors that influence proenvironmental behaviours. The purpose of this paper is identify characteristic pro-environmental behaviours. This study use factor analysis to reduce factor determinant and survei to collect the data. The survey tool used the theory of planned behaviour (TPB) throughout the questionnaire which had shared to 400 college students. Result of this study conclude pro-environmental behaviours is influenced by attitudes, subjective norms, perceived control, perceived consequences, and situational factors, behaviour intention.
\end{abstract}

Keyword: pro-environmental behaviours; campus sustainability; factor analysis

\section{Pendahuluan}

Munculnya tantangan lingkungan global, seperti perubahan iklim, penipisan sumber daya, atau hilangnya keanekaragaman hayati merupakan hal yang perlu diwaspadai oleh pihak terkait.Upaya mengatasi dampak lingkungan harus segera dilakukan, seperti memahami perilaku manusia yang memicu terjadinya tantangan tersebut dan memprediksi perubahan kondisi yang berpengaruh dalam menurunkan dampak lingkungan. Perubahan kondisi lingkungan global dipengaruhi oleh perkembangan teknologi, kebijakan yang tidak pro lingkungan, serta perilaku manusia.Perilaku manusia secara signifikan memberikan kontribusi terhadap lingkungan global, sehingga perubahan perilaku berpotensi untuk mengurangi dampak lingkungan.

\footnotetext{
${ }^{*}$ Penulis Korespondensi.

email: asrirachmawati22@yahoo.com, naniekh@yahoo.com
}

J@TI Undip, Vol IX, No 3, September 2014

Oleh karena itu, untuk memahami alasan individu dalam menentukan tindakan dan keputusan mereka dalam menghadapi tantangan lingkungan global, perlu diidentifikasi faktor-faktor penentu perilaku lingkungan manusia sebagai individu.

Sejak tahun 1980, peneliti dalam bidang psikologi lingkungan telah berkontribusi dalam menguji beberapa teori dan model yang bertujuan untuk memprediksi perilaku lingkungan yang relevan dan mengidentifikasi hal-hal yang memicu manusia untuk mengubah perilaku pro lingkungan.Terdapat beberapa model yang dikembangkan dalam psikologi lingkungan yang dijadikan acuan oleh peneliti yang dianggap berdampak relevan terhdapa perilaku lingkungan (Klockner, 2013).Theory of Planned Behaviour(TPB)yang dikemukakan oleh Ajzen (1991) dalam (Tonglet dkk, 2004) merupakan salah satu model yang sering dijadikan referensi dalam menjelaskan determinan perilaku tertentu. 
Pendidikan merupakan salah satu variabel yang penting dalam menjelaskan tingkat perhatian dan perilaku lingkungan (Zilahy dan Huisingh, 2009; Zsóka dkk, 2012). Peneliti terdahulu menunjukkan bahwa orang yang lebih tinggi tingkat pendidikan lebih peduli tentang kualitas lingkungan dan termotivasi untuk terlibat langsung dalam upaya kelestarian lingkungan. Hal ini disebabkan adanya kesadaran akan potensi kerusakan (Lozano, 2006). Universitas merupakan sarana pendidikan yang berperan dalam mengarahkan mahasiswa untuk memiliki kepedulian sosial secara efektif (Frank dan Meyer, 2007). Kampus yang berwawasan lingkunganmenjadi wacana penting pada berbagai perguruan tinggi dalam memberikan sumbangsih untuk mengatasi permasalahan lingkungan secara global. Sistem Manajemen Lingkungan (Enviromental Management System) telah diterapkan di beberapa universitas Eropa sebagai cara mendukung program kampus yang berkelanjutan (Disterheft dkk, 2012 dalam Geng dkk, 2013).

Berdasarkan latar belakang tersebut, penelitian ini bertujuan untuk mengidentifikasi karakteristik perilaku pro-lingkungan dalam mendukung program campus sustainability. Hasil penelitian ini diharapkan mampu mendukung pengembangan model penilaian keberhasilan program campus sustainability.

\section{Metodologi Penelitian}

\section{Theory of Planned Behaviour}

Penelitian yang dilakukan oleh Tonglet dkk (2004) menjelaskan bahwa adanya korelasi antara faktor prediksi perilaku dengan intensi perilaku.Namun, pada penelitian Davis dkk (2008) menghasilkan bahwa adanya korelasi secara langsung antara perilaku dengan faktor prediksi perilaku. Menurut TPB, intensi dipengaruhi oleh tiga faktor, yaitu sikap, norma subyektif, dan persepsi kendali perilaku (Tonglet dkk, 2004). Pada penelitian ini selain menggunakan model TPB, juga menambahkan faktor-faktor intensi perilaku berupa faktor situasional dan persepsi konsekuensi.Berikut faktorfaktor intensi perilaku yang digunakan dalam penelitian ini:

a. Sikap

Davis dkk (2008) menyatakan sikapmerupakan persepsi seseorang memiliki penilaian menguntungkan atau tidak menguntungkan dari perilaku yang bersangkutan. Sementara itu, Ajzen dalam Tonglet dkk (2004) menunjukkan bahwa sikap cenderung prediktor penting dari perilaku, sikap memberikan kontribusi yang signifikan terhadap prediksi niat. Davis dkk (2008) dalam penelitiannya menunjukkan adanya korelasi antara sikap dengan perilaku.

b. Norma Subyektif

Menurut Davis dkk (2008),norma subyektif merupakan persepsi individu dari tekanan sosial yang dirasakan untuk melakukan atau tidak melakukan suatu perilaku.Sementara itu, Wan dkk
(2012) menjelaskan bahwa tekanan sosial merupakan faktor penting dalam memotivasi perilaku. Davis dkk (2008) dalam penelitiannya juga menunjukkan adanya korelasi antara norma subyektif dengan perilaku.

c. Persepsi Kendali Perilaku

Davis dkk (2008) menyatakan persepsi kendali perilaku merupakan persepsi individu terhadap kemudahan atau kesulitan melakukan perilaku dan diasumsikan untuk mencerminkan pengalaman masa lalu serta mengantisipasi hambatan dan rintangan. Berdasarkan TPB, Tonglet dkk (2004) mengasumsikan bahwa seseorang dengan persepsi kendali perilaku yang kuat akan memiliki intensi yang kuat untuk melakukan perilaku bersangkutan. Davis dkk (2008) dalam penelitiannya juga menunjukkan adanya korelasi antara persepsi kendali perilaku dengan perilaku.

d. Persepsi Konsekuensi

Davis dkk (2008) menjelaskan persepsi konsekuensi merupakan persepsi individu mengenai hasil dari perilaku yang telah dilakukandan hasil sumber daya lainnya yang efisien. Dan menunjukkan bahwa persepsi konsekuensi merupakan prediktor signifikan untuk lima persen variansi dalam perilaku.

e. Faktor Situasional

Menurut Davis dkk (2008),faktor situasionalmerupakan faktor fisik yang dapat memfasilitasi atau menghambat perilaku.Davis dkk (2008) dalam penelitiannya juga menunjukkan adanya korelasi antara faktor situasional dengan perilaku. Sementara itu, Tonglet dkk (2004) menunjukkan korelasi terbesar terhadap intensi perilaku salah satunya adalah faktor situasional.

\section{Pengumpulan Data}

Pengumpulan data dilakukan dengan metode survei menggunakan serangkaian kuesioner penelitian. Survei dilakukan dengan melakukan wawancara terhadap 200 mahasiswa. Kuesioner yang digunakan adalah kuesioner dengan skala likert kontinu, agar terdapat keluasan dalam memberikan jawaban dalam setiap item pertanyaan. Skala likert dengan tipe kontinu memiliki rentang skala 1-10 yang menyatakan responden sangat tidak setuju sampai sangat setuju. Penyusunan kuesioner berkaitan dengan butir-butir pertanyaan yang disesuaikan dengan variabel-variabel yang diteliti.

\section{Tahapan Penelitian}

Langkah-langkah yang dilakukan dalam penelitian ini adalah sebagai berikut:

1. Melakukan uji asumsi yang meliputi uji kelayakan analisis faktor dengan menggunakan uji Kaiser Meyer Olkin (KMO). Nilai KMO digunakan untuk membandingkan nilai koefisien korelasi dengan koefisien korelasi parsialnya. 
Nilai KMO yang dikatakan layak untuk analisis faktor adalah sebesar lebih dari 0,5 (KMO $\geq 0,5)$.

2. Melakukan uji korelasi dengan menggunakan uji Barlett untuk melihat signifikasi dari semua korelasi. Nilai signifikansi $<0,05$ yang menunjukkan terjadinya korelasi antar variabel.

3. Menentukan matriks anti-image, berdasarkan nilai Measure of Sampling Adequancy (MSA) dapat diketahui derajat korelasi antar atribut yaitu atribut mana yang dapat diproses lebih lanjut dan atribut mana yang harus dikeluarkan. Variabel layak dianalisis lebih lanjut dengan kriteria nilai MSA $>0,5$.

4. Menentukan jumlah faktor bersama atau faktor laten yang dipertahankan dengan melihat nilai eigen.Atribut yang dapat dipertahankan sebagai faktor bersama adalah atribut yang memiliki nilai eigen lebih besar atau sama dengan 1. Faktor lain yang memiliki nilai eigen kurang dari 1 tidak dimasukkan ke dalam model. Nilai eigen menunjukkan besarnya sumbangan dari faktor terhadap varians seluruh variabel asli.

\section{Hasil Dan Pembahasan}

\section{Analisis Faktor}

a. Nilai Keiser Mayeer Olkin (KMO) dan Uji Barlett Berdasarkan tabel 1 terlihat bahwa semua variabel menunjukkan nilai $\mathrm{KMO} \geq 0,5$ dan tingkat signifikansi $0,00<0,05$, artinya data yang diperoleh lebih dari cukup dan layak untuk dianalisis dengan analisis faktor.

Tabel 1. Nilai KMO dan Uji Barlett

\begin{tabular}{lcc}
\hline \multicolumn{1}{c}{ Variabel } & KMO & $\begin{array}{c}\text { Uji Barlett } \\
\text { (nilai sig.) }\end{array}$ \\
\hline Sikap & 0,772 & 0,00 \\
Norma Subyektif & 0,822 & 0,00 \\
Persepsi Kendali & 0,719 & 0,00 \\
Perilaku & 0,598 & 0,00 \\
Faktor Situasional & 0,866 & 0,00 \\
Persepsi & 0,661 & 0,00 \\
Konsekuensi & 0,615 & 0,00 \\
Intensi Perilaku & 0 \\
Perilaku &
\end{tabular}

b. Matriks Anti-Image

Nilai Measure of Sampling Adequancy (MSA) menyatakan derajat korelasi antar atribut yaitu atribut mana yang dapat diproses lebih lanjut dan atribut mana yang harus dikeluarkan. Berdasarkan hasil perhitungan pada tabel 2 terlihat bahwa semua atribut memiliki nilai MSA lebih dari 0,5, artinya tidak ada atribut yang dikeluarkan dari analisis sehingga atribut dapat digunakan untuk analisis selanjutnya.

c. Reduksi Faktor

Tahap berikutnya adalah menentukan nilai eigen dari masing-masing atribut, digunakan untuk mereduksi atribut-atribut yang ada menjadi faktor baru.

Tabel 2. Hasil Perhitungan Matriks AntiImage(berlanjut)

\begin{tabular}{|c|c|c|}
\hline Variabel & Komponen & Nilai MSA \\
\hline \multirow[t]{4}{*}{ Sikap } & ATTD1 & 0,738 \\
\hline & ATTD2 & 0,738 \\
\hline & ATTD3 & 0,818 \\
\hline & ATTD4 & 0,817 \\
\hline \multirow[t]{9}{*}{ Norma Subyektif } & SN1 & 0,893 \\
\hline & $\mathrm{SN} 2$ & 0,826 \\
\hline & $\mathrm{SN} 3$ & 0,837 \\
\hline & SN4 & 0,871 \\
\hline & SN5 & 0,828 \\
\hline & SN6 & 0,866 \\
\hline & SN7 & 0,902 \\
\hline & SN8 & 0,6 \\
\hline & SN9 & 0,557 \\
\hline \multirow{5}{*}{$\begin{array}{l}\text { Persepsi Kendali } \\
\text { Perilaku }\end{array}$} & PBC1 & 0,67 \\
\hline & PBC2 & 0,704 \\
\hline & PBC3 & 0,806 \\
\hline & PBC4 & 0,718 \\
\hline & PBC5 & 0,688 \\
\hline \multirow[t]{4}{*}{ Faktor Situasional } & SF1 & 0,569 \\
\hline & SF2 & 0,58 \\
\hline & SF3 & 0,651 \\
\hline & SF4 & 0,633 \\
\hline \multirow{9}{*}{$\begin{array}{l}\text { Persepsi } \\
\quad \text { Konsekuensi }\end{array}$} & PC1 & 0,816 \\
\hline & PC2 & 0,851 \\
\hline & PC3 & 0,891 \\
\hline & PC4 & 0,898 \\
\hline & PC5 & 0,858 \\
\hline & PC6 & 0,859 \\
\hline & PC7 & 0,883 \\
\hline & PC8 & 0,872 \\
\hline & PC9 & 0,866 \\
\hline \multirow[t]{3}{*}{ Intensi Perilaku } & IP1 & 0,619 \\
\hline & IP2 & 0,627 \\
\hline & IP3 & 0,824 \\
\hline \multirow[t]{6}{*}{ Perilaku } & PR1 & 0,649 \\
\hline & PR2 & 0,585 \\
\hline & PR3 & 0,577 \\
\hline & PR4 & 0,726 \\
\hline & PR5 & 0,628 \\
\hline & PR6 & 0,64 \\
\hline
\end{tabular}

Variabel Sikap

Tabel 3 merupakan hasil perhitungan nilai eigen dari variabel sikap.

Tabel 3. Hasil Perhitungan Nilai Eigen Variabel Sikap

\begin{tabular}{|c|c|c|c|c|}
\hline \multirow{3}{*}{ Variabel } & \multirow{3}{*}{ Komponen } & \multicolumn{3}{|c|}{ Initial Eigenvalues } \\
\hline & & & $\%$ of & $\%$ of \\
\hline & & Total & variance & Cum \\
\hline \multirow{4}{*}{ Sikap } & 1 & 2,888 & 72,193 & 72,193 \\
\hline & 2 & 0,558 & 13,961 & 86,154 \\
\hline & 3 & 0,344 & 8,599 & 94,753 \\
\hline & 4 & 0,21 & 5,247 & 100 \\
\hline
\end{tabular}


Tabel 3 menunjukkan terdapat 1 faktor atau komponen yang nilai eigennya lebih dari 1 , yaitu komponen 1, sehingga diperoleh jumlah faktor yang terbentuk adalah sebanyak satu faktor. Tabel 3 juga menjelaskan bahwa jika 4 komponen tersebut dijadikan satu faktor, maka faktor tersebut mampu menjelaskan ragam dari komponen sebesar 75,011\%.

Variabel Norma Subyektif

Tabel 4 merupakan hasil perhitungan nilai eigen dari variabel norma subyektif.

Tabel 4. Hasil Perhitungan Nilai Eigen Variabel Norma Subyektif

\begin{tabular}{|c|c|c|c|c|}
\hline \multirow[b]{2}{*}{ Variabel } & \multirow[b]{2}{*}{ Komponen } & \multicolumn{3}{|c|}{ Initial Eigenvalues } \\
\hline & & Total & $\begin{array}{l}\text { \% of } \\
\text { variance }\end{array}$ & $\begin{array}{l}\text { \% of } \\
\text { Cum }\end{array}$ \\
\hline \multirow{9}{*}{$\begin{array}{c}\text { Norma } \\
\text { Subyektif }\end{array}$} & 1 & 4,056 & 45,062 & 45,062 \\
\hline & 2 & 1,674 & 18,6 & 63,662 \\
\hline & 3 & 1,029 & 11,436 & 75,098 \\
\hline & 4 & 0,578 & 6,423 & 81,521 \\
\hline & 5 & 0,462 & 5,137 & 86,658 \\
\hline & 6 & 0,414 & 4,603 & 91,261 \\
\hline & 7 & 0,314 & 3,491 & 94,752 \\
\hline & 8 & 0,274 & 3,047 & 97,799 \\
\hline & 9 & 0,198 & 2,199 & 100 \\
\hline
\end{tabular}

Tabel 4 menunjukkan terdapat tiga faktor atau komponen yang nilai eigennya lebih dari 1 , yaitu komponen 1, 2, dan 3, sehingga diperoleh jumlah faktor yang terbentuk adalah sebanyak 3 faktor. Tabel 4 juga menjelaskan bahwa jika 9 komponen tersebut dijadikan satu faktor, maka faktor tersebut mampu menjelaskan ragam dari komponen sebesar 45,062\%. Apabila dari 9 komponen tersebut dijadikan 3 faktor, maka ketiga faktor tersebut mampu menjelaskan ragam komponen sebesar 75,098\%.

Variabel Persepsi Kendali Perilaku

Tabel 5 merupakan hasil perhitungan nilai eigen dari variabel persepsi kendali perilaku.

Tabel 5. Hasil Perhitungan Nilai Eigen Variabel Persepsi Kendali Perilaku

\begin{tabular}{ccccc}
\hline \multirow{2}{*}{ Variabel } & \multirow{2}{*}{ Komponen } & \multicolumn{3}{c}{ Initial Eigenvalues } \\
\cline { 3 - 5 } & & Total & $\begin{array}{l}\text { \% of } \\
\text { variance }\end{array}$ & \% of \\
& & 2,539 & 50,776 & 50,776 \\
\hline \multirow{3}{*}{ Persepsi } & 2 & 1,07 & 21,404 & 72,18 \\
Kendali & 3 & 0,597 & 11,943 & 84,123 \\
Perilaku & 4 & 0,428 & 8,562 & 92,685 \\
& 5 & 0,366 & 7,314 & 100 \\
\hline
\end{tabular}

Tabel 5 menunjukkan terdapat 2 faktor atau komponen yang nilai eigennya lebih dari 1 , yaitu komponen 1 dan 2, sehingga diperoleh jumlah faktor yang terbentuk adalah sebanyak 2faktor. Tabel 5 juga menjelaskan bahwa jika 5komponen tersebut dijadikan satu faktor, maka faktor tersebut mampu menjelaskan ragam dari komponen sebesar 50,776\%. Apabila dari 5komponen tersebut dijadikan 2 faktor, maka kedua faktor tersebut mampu menjelaskan ragam komponen sebesar $72,18 \%$.

Variabel Faktor Situasional

Tabel 6 merupakan hasil perhitungan nilai eigen dari variabel faktor situasional.

Tabel 6. Hasil Perhitungan Nilai Eigen Variabel Faktor Situasional

\begin{tabular}{|c|c|c|c|c|}
\hline \multirow[b]{2}{*}{ Variabel } & \multirow[b]{2}{*}{ Komponen } & \multicolumn{3}{|c|}{ Initial Eigenvalues } \\
\hline & & Total & $\begin{array}{l}\text { \% of } \\
\text { variance }\end{array}$ & $\begin{array}{l}\text { \% of } \\
\text { Cum }\end{array}$ \\
\hline & 1 & 1,766 & 44,139 & 44,139 \\
\hline Faktor & 2 & 1,019 & 25,48 & 69,619 \\
\hline Situasional & 3 & 0,692 & 17,31 & 86,929 \\
\hline & 4 & 0,523 & 13,071 & 100 \\
\hline
\end{tabular}

Tabel 6 menunjukkan terdapat 2 faktor atau komponen yang nilai eigennya lebih dari 1 , yaitu komponen1 dan 2, sehingga diperoleh jumlah faktor yang terbentuk adalah sebanyak 2 faktor. Tabel 6 juga menjelaskan bahwa jika 4komponen tersebut dijadikan satu faktor, maka faktor tersebut mampu menjelaskan ragam dari komponen sebesar 44,139\%. Apabila dari 4komponen tersebut dijadikan 2 faktor, maka kedua faktor tersebut mampu menjelaskan ragam komponen sebesar 69,619\%.

\section{Variabel Persepsi Konsekuensi}

Berikut tabel 7 merupakan hasil perhitungan nilai eigen dari variabel persepsi konsekuensi.

Tabel 7. Hasil Perhitungan Nilai Eigen Variabel Persepsi Konsekuensi

\begin{tabular}{ccccc}
\hline \multirow{2}{*}{ Variabel } & \multirow{3}{*}{ Komponen } & \multicolumn{3}{c}{ Initial Eigenvalues } \\
\cline { 3 - 5 } & & To of & \% of \\
variance & Cum \\
\hline & 1 & 4,516 & 50,197 & 50,197 \\
& 3 & 1,187 & 13,191 & 63,388 \\
Persepsi & 4 & 0,849 & 9,437 & 72,825 \\
Konsekuensi & 5 & 0,724 & 8,042 & 80,867 \\
& 6 & 0,493 & 4,482 & 85,349 \\
& 7 & 0,376 & 4,172 & 89,521 \\
& 8 & 0,335 & 3,726 & 93,247 \\
& 9 & 0,235 & 3,163 & 96,41 \\
& & & & \\
\hline
\end{tabular}

Tabel 7 menunjukkan terdapat 2 faktor atau komponen yang nilai eigennya lebih dari 1 , yaitu komponen 1 dan 2, sehingga diperoleh jumlah faktor yang terbentuk adalah sebanyak 2 faktor. Tabel 7 juga menjelaskan bahwa jika 9 
komponen tersebut dijadikan satu faktor, maka faktor tersebut mampu menjelaskan ragam dari komponen sebesar 50,197\%. Apabila dari 9 komponen tersebut dijadikan 2 faktor, maka kedua faktor tersebut mampu menjelaskan ragam komponen sebesar 63,388 \%.

\section{Variabel Intensi Perilaku}

Tabel 8 merupakan hasil perhitungan nilai eigen dari variabel intensi perilaku.

Tabel 8. Hasil Perhitungan Nilai Eigen Variabel Intensi Perilaku

\begin{tabular}{|c|c|c|c|c|}
\hline \multirow{3}{*}{ Variabel } & \multirow{3}{*}{ Komponen } & \multicolumn{3}{|c|}{ Initial Eigenvalues } \\
\hline & & & $\%$ of & $\%$ of \\
\hline & & Total & variance & Cum \\
\hline \multirow{3}{*}{$\begin{array}{c}\text { Intensi } \\
\text { Perilaku }\end{array}$} & 1 & 2,139 & 71,287 & 71,287 \\
\hline & 2 & 0,588 & 19,584 & 90,871 \\
\hline & 3 & 0,274 & 9,129 & 100 \\
\hline
\end{tabular}

Tabel 8 menunjukkan terdapat 1 faktor atau komponen yang nilai eigennya lebih dari 1 , yaitu komponen1, sehingga diperoleh jumlah faktor yang terbentuk adalah sebanyak 1 faktor. Tabel 8 juga menjelaskan bahwa jika 3komponen tersebut dijadikan satu faktor, maka faktor tersebut mampu menjelaskan ragam dari komponen sebesar 71,287\%.

\section{Variabel Perilaku}

Tabel 9 merupakan hasil perhitungan nilai eigen dari variabel perilaku.

Tabel 9. Hasil Perhitungan Nilai Eigen Variabel Perilaku

\begin{tabular}{|c|c|c|c|c|}
\hline \multirow{3}{*}{ Variabel } & \multirow{3}{*}{ Komponen } & \multicolumn{3}{|c|}{ Initial Eigenvalues } \\
\hline & & & $\%$ of & $\% o f$ \\
\hline & & Total & variance & Cum \\
\hline \multirow{6}{*}{ Perilaku } & 1 & 1,991 & 33,18 & 33,18 \\
\hline & 2 & 1,015 & 16,923 & 50,103 \\
\hline & 3 & 0,965 & 16,076 & 66,179 \\
\hline & 4 & 0,837 & 13,955 & 80,134 \\
\hline & 5 & 0,738 & 12,307 & 92,441 \\
\hline & 6 & 0,454 & 7,559 & 100 \\
\hline
\end{tabular}

Tabel 9 menunjukkan terdapat 2 faktor atau komponen yang nilai eigennya lebih dari 1 , yaitu komponen 1 dan 2 , sehingga diperoleh jumlah faktor yang terbentuk adalah sebanyak 2 faktor. Tabel 9 juga menjelaskan bahwa jika 6 komponen tersebut dijadikan satu faktor, maka faktor tersebut mampu menjelaskan ragam dari komponen sebesar 33,18\%. Apabila dari 6 komponen tersebut dijadikan 2 faktor, maka kedua faktor tersebut mampu menjelaskan ragam komponen sebesar 50,103\%.
Dapat disimpulkan dari keseluruhan variabel yang diteliti menunjukkan nilai KMO > 0,5 dan tingkat signifikansi $<0,05$ sehingga data layak dianalisis lebih lanjut. Semua atribut memiliki nilai MSA lebih dari 0,5, artinya tidak ada atribut yang dikeluarkan dari analisis sehingga dapat digunakan.

Pada variabel sikap, hasil perhitungan menunjukkan bahwa diperoleh jumlah faktor sebanyak 1, faktor tersebut mampu menjelaskan ragam dari komponen sebesar 75,011\%. Hasil perhitungan pada variabel norma subyektif menunjukkan bahwa faktor yang diperoleh sebanyak 3 faktor, ketiga faktor tersebut mampu menjelaskan ragam komponen sebesar $75,098 \%$. Jumlah faktor yang diperoleh pada variabel persepsi kendali perilaku yaitu sebanyak 2 faktor, kedua faktor tersebut mampu menjelaskan ragam komponen sebesar 72,18\%. Pada variabel faktor situasional menunjukkan bahwa jumlah faktor yang diperoleh sebanyak 2 faktor, kedua faktor tersebut mampu menjelaskan ragam komponen sebesar 69,619\%. Kemudian hasil perhitungan pada variabel persepsi konsekuensi, jumlah faktor yang diperoleh sebanyak 2, kedua faktor tersebut mampu menjelaskan ragam komponen sebesar 63,388 \%. Sedangkan pada variabel intensi perilaku menunjukkan bahwa jumlah faktor yang diperoleh sebanyak 1 faktor, faktor tersebut mampu menjelaskan ragam dari komponen sebesar 71,287 \%. Hasil perhitungan variabel perilaku, jumlah faktor yang diperoleh sebanyak 2 faktor, kedua faktor tersebut mampu menjelaskan ragam komponen sebesar 50,103\%.

\section{Kesimpulan}

Penelitian ini dilakukan untuk mengidentifikasi faktor determinan perilaku pro lingkungan dalam mendukung program campus sustainability. Berdasarkan hasil penelitian yang dilakukan terhadap mahasiswa Universitas Diponegoro, diperoleh kesimpulan bahwa faktor-faktor yang berpengaruh terhadap perilaku pro lingkungan adalah sikap, norma subyektif, persepsi kendali perilaku, faktor situasional, persepsi konsekuensi, intensi perilaku, perilaku. Publikasi berikutnya akan membahas pengaruh variabel moderating untuk menentukan model terbaik dalam penilaian keberhasilan program campus sustainability.

\section{Daftar Pustaka}

Ajzen, I. 1991. The theory of planned behaviour.Organizational behaviour and human decision process. 50, 179-211 dalam Tonglet, M., Phillips, P.S., Read, A.D. 2004. Using the Theory of Planned Behaviour to investigate the determinants of recycling behaviour: a case study from Brixworth, UK. Resources, Conservation and Recycling. 41, 191-214. 
Davis, G., O'Callaghan, F., Knox, K. 2008. Sustainable attitudes and behaviours amongst a sample of non-academic staf, a case study from an information services department, Griffith University, Brisbane. International Journal of Sustainability in Hiigher Education. 10(2), 136151.

Disterheft, A., Caeiro, S.S.F., Ramos, M.R., Azeiteiro, U.M. 2012. Environmental Management Systems (EMS) implementation processes and practices in European higher education institutions-Top-down versus participatory approaches. J. Clean. Prod.31, 8090 dalam Geng, Y., Liu, K., Xue, B., Fujita, T. 2013. Creating a "green university" in China: a case of Shenyang University. J. Cleaner Production. 61, 13-19.

Frank, D.J., Meyer, J.W. 2007. University expansion and the knowledge society. Theor. Soc. 36, 287311.

Klockner, C.A. 2013. Comprehensive model of the psychology of environmental behaviour-A meta-analysis. Global Environmental Change 23, 1028-1038
Lozano, R. 2006. Incorporation and institutionalization of $\mathrm{SD}$ into universities: breaking through barries to change.J. Clean. Prod. 14, 787-796.

Tonglet, M., Phillips, P.S., Read, A.D. 2004. Using the Theory of Planned Behaviour to investigate the determinants of recycling behaviour: a case study from Brixworth, UK. Resources, Conservation and Recycling. 41, 191-214.

Wan, C., Cheung, R., Shen, G.Q. 2012. Recycling attitude and behaviour in university campus: a case study in Hong Kong. Facilities. 30(13/14), 630-646.

Zilahy, G., Huisingh, D. 2009. The roles of academia in regional sustainability initiatives. J. Clean. Prod. 17 (2), 1057-1066.

Zsóka, A., Szerényi, Z., Széchy, A., Kocsis, T. 2012. Greening due to environmental education? Environmental knowledge, attitude, consumer behaviour and everyday pro-environmental activities of Hungarian high school and university students. J. Clean. Prod. 48, 126-138. 